\title{
Impact of modification of sand-lime mass with organic compounds on the microstructure and mechanical features of silicate bricks
}

\author{
Ryszard Dachowski, Anna Stepien \\ Kielce University of Technology, Department of civil and environmental engineering, Al. 1000-lecia P.P.7, 25-317 Kielce, Poland
}

\begin{abstract}
The aim of conducted research is to modify sand-lime blocks with organic compounds, which in turn leads primarily to increase their strength characteristics and resistant to injury.

The liquid admixture of organic compounds, which are rich in certain elements, chemical compounds and macro-, micro- and ultraelements (among others colloidal silica or phosphorus) beneficial effects on a number of chemical transformations in the manufacturing process of this products.

The SEM (Scanning Electron Microscope) examination enabled the phase composition analysis of the modified products.

Occurring transformations have an impact on the phase microstructure (C-S-H phase is remodeling, C-S-H is Calcium Silicate Hydrates $\mathrm{CaO}-\mathrm{SiO}_{2}-\mathrm{H}_{2} \mathrm{O}$ and and calcium silicate hydrates of arranged structure, i.e. tobermorite), the porosity and physical and mechanical properties of the final product, which is a sand-lime block.

The research demonstrated that the application of organic compounds to silicate products led to the creation of the following phase known as tobermorite and sometimes xonotlite.

Sand-lime products are a group of construction materials used to erect external and internal walls of buildings. Are called an environmentally friendly, because these products consist only of sand, lime and water. The aim of conducted modification, besides improving features of studied material, is to retain its naturalness and therefore used admixtures are also analyzed in order to estimate their influence on the environment and human.
\end{abstract}

Keywords: Calcium Silicate Hydrates; C-S-H; tobermorite; silicates; sand-lime blocks; organic compounds.

\begin{tabular}{|ll|}
\hline Nomenclature \\
SEM & scanning electron microscope \\
XRD & X-ray diffractometry \\
C-S-H & Calcium Silicate Hydrates \\
$\sigma$ & compressive strength $[\mathrm{MPa}]$ \\
$\rho$ & density $\left(\mathrm{kg} / \mathrm{dm}^{3}\right)$ \\
\hline
\end{tabular}

\section{Introduction}

Sand-lime products for a long time have been used to build farm buildings or other objects referred to as second-class structures. Their functional properties have been omitted, which was a consequence of a very small knowledge of their internal structure, and this in turn is a response to the physical and mechanical properties of all products used not only in the construction industry. The appearance and development of methods and interpretation of test results, giving answers to many questions in the field of microstructure, has become a milestone in the study of internal structure of materials, including building ones. Tests such as structural X-ray (XRD) and scanning electron microscopy (SEM, Cryo-SEM, TEM) provide a number of relevant information on the internal structure and compounds formed in the production process. In the era of any modifications to which materials are subjected this is a phenomenon of such importance, because it indicates directions for further research opportunities, often very accurate.

Corresponding author: Ryszard Dachowsk. E-mail address: tobrd@tu.kielce.pl

http://dx.doi.org/10.3846/enviro.2014.011

(C) 2014 The Authors. Published by VGTU Press. This is an open-access article distributed under the terms of the Creative Commons Attribution License, which permits unrestricted use, distribution, and reproduction in any medium, provided the original author and source are credited. 
The one responsible for technological progress in the construction of microscopes was M.Knoll, who in 1935 designed the first transmission electron microscope. Next important event took place three years later, when the German Manfred von Ardenne installed to transmission microscopy beam deflection coils. The German physicist invention became the prototype of a scanning electron microscope, which we know today. The first commercial SEM was produced in 1965 by the British company Cambridge Scientific Instruments.

Scanning electron microscopy (SEM) is a method that allows the study of microstructural characteristics of objects. Scanning electron microscope is a device that uses a stream of orientated electrons, and these, in turn, line by line, sweep the surface of the sample and make its image [7].

Studies using a scanning electron microscope have allowed to examine the functional properties with the microstructure [10].

X-ray diffractometry or x-ray crystallography (XRD) is a method commonly used in biotechnology, organic chemistry, or in the construction industry. The chemical structure of concretes have been examined very carefully [1, 2, 3, 10, 11], and works on them and further modification are still ongoing. XRD analysis is non-destructive testing (so the sample can be used for further research) which enables to specify the compounds that were formed during the manufacture of the product.

Sand-lime elements, also known as calcium silicate products, are natural and ecological building material. They are formed from natural substrates, i.e. sand, lime and water. Traditional silicate products have a very good physical and mechanical properties. They are characterized by a high compressive strength (approx. $20 \mathrm{MPa}$ ) in comparison to other masonry units, high resistance to weather factors, biological corrosion resistance and capacity for accumulation of heat and moisture. The addition of lime and high $\mathrm{pH}$ prevent the fungal growth and other similar microorganisms over the walls made of them. Since 2006 a sharp increase in global interest in silicates has been observed [4, 5, 12]. The development of civilization, and then the environmental protection, have provoked changes also in the materials sector. Actions aimed at improving the physical and mechanical properties of sand lime products combined with material recovery have been taken [6].

In recent years the use of waste and organic materials in products manufacturing has become a beneficial solution. Organic compounds, rich in numerous substances or chemical elements conducive to phase changes, are a natural way to increase the efficiency and properties of the modified product.

The manufacturing process of silicate products uses slaked lime. Water is a substrate responsible for the correct course of chemical reactions, and its amount has an influence on microstructural changes of the tested products. Prepared sand-lime mixture is molded under pressure and temperature of approx. $203{ }^{\circ} \mathrm{C}$. During autoclaving process (so-called hydrothermal treatment), under the action of pressure, calcium silicates $\mathrm{CaSiO}_{3}$ arise as a result of a strong combination of silica with lime. Next, due to chemical reaction, calcium carbonate $\mathrm{CaCO}_{3}$ is formed. As a result of chemical reaction lime binds with $\mathrm{SiO}_{2}$ (silicon dioxide), which is the main component of the sand used in the production of sand-lime products.

$$
2 \mathrm{Ca}(\mathrm{OH})_{2}+\mathrm{SiO}_{2}=>2 \mathrm{CaO} * \mathrm{SiO}_{2} * 2 \mathrm{H}_{2} \mathrm{O}
$$

The topic of hydrated calcium silicates in concretes is widely described in the literature, but the internal structure of other construction materials is still significantly ignored. In the process of hydrothermal treatment, like in the concrete, also in sand lime products hydrated calcium silicates are present with different degrees of crystallinity or structure arrangement. Most attention is paid to the C-S-H phase (Calcium Silicate hydrates), which is formed as the first one and occurs in several specific forms [9]. In the products resulting from the hydrothermal treatment the solubility of silica increases and the solubility of calcium hydroxide $\mathrm{Ca}(\mathrm{OH})_{2}$ decreases. This causes significant growth in the rate of reaction of silica with calcium hydroxide or with calcium silicates and the creation of hydrated phases.

C-S-H phase (hydrated calcium silicate, with a disordered structure) has very amorphous nature. The precursor of studies on mentioned phase was Taylor. He gave the crystallographic data of C-S-H phase and described the structure of the phases (one of them was to be similar to tobermorite and the second one - to jennite) already in 1950. Taylor's considerations have been developed by Nonat [3]. Because of experimental difficulties the composition of liquid phase forming in equilibrium with the solid phases under high temperature and increased pressure is still unknown.

The presence of aluminum (Al) favors the formation of higher forms of hydrated calcium silicates with ordered structure The most perfect form of C-S-H phase is tobermorite (Figs 1, 2). Tobermorite may have two forms. Observed under a scanning electron microscope shows a cross-section in the form of blades. It may also be similar to honeycomb or form well shaped spherical aggregations. There are many hydrated calcium silicate, which is a consequence of the ability of calcium atom to form a coordination polyhedron $\mathrm{CaO}_{6}$ of suitable dimensions $[3,8,9,10]$.

Compressive strength test, water absorption and water absorption due to capillary raising testes have been conducted in order to verify the extent to which the microstructure affects the basic properties of sand-lime products.

\section{Methodology and purpose of conducted research}

Two types of silicate products were subjected to tests - traditional sand-lime product and modified with organic compounds. The interpretation of the microstructure was performed on the basis of electron scanning microscopy (SEM-type IROL 5400 cooperating with the analyzer EDS) and X-ray diffraction (XRD-Empyrean, PANALYTICAL).

Widely used in science, technology and industry, scanning electron microscope was applied for quantitative analysis of the elemental composition and distribution of elements in the tested area of the samples. The sample surface was swept by 
electron probe under voltage of 5-50 eV. On the basis of the obtained images the analysis of the microstructure and phase composition of the tested products was possible. SEM examination was preceded by a performance of analysis of the composition of compounds and phases formed during the manufacture of the products.

During the experiments laboratory samples of both traditional and modified silicate products were prepared each time $[13,14,15,16]$. The dimensions of the samples were $40 \times 40 \times 160 \mathrm{~mm}$. After the laboratory tests full silicate brick with dimensions $180 \times 220 \times 250 \mathrm{~mm}$ were made.

Compressive strength test of laboratory samples with dimensions of $40 \times 40 \times 160 \mathrm{~mm}$ was conducted using a press Tecnotest KC 300.

Each test was performed in accordance with applicable standard, was conducted in collaboration with the Silicate Production Plant in Ludynia and was a half-industrial research.

\section{Test results}

Sand-lime products were modified with respectively $1 \%, 5 \%$ and $10 \%$ of organic matter in liquid form. Gradually increasing amount of organic compounds results in excessive liquefaction of silicate mass, making it impossible to be formed in blocks. This percentage of the substance applied to the modification was dictated by the earlier technical and economic analysis. Most advantageous, and thus most proper, turned out to be the modification of sand-lime mass with 5\% of the organic matter. The compressive strength $(\sigma)$ of so modified product increased from $20 \mathrm{MPa}$ to $35.82 \mathrm{MPa}$. The weight of tested product, and therefore its bulk density $(\rho)$, was also higher (from the value of $1.73 \mathrm{~kg} / \mathrm{dm}^{3}$ to $2.05 \mathrm{~kg} / \mathrm{dm}^{3}$ ).

Images of modified silicate products, obtained from the scanning electron microscope (SEM), revealed the presence of amorphous $\mathrm{C}-\mathrm{S}-\mathrm{H}$ phase and tobermorite phase, known as its most perfect form and characterized by an ordered structure.

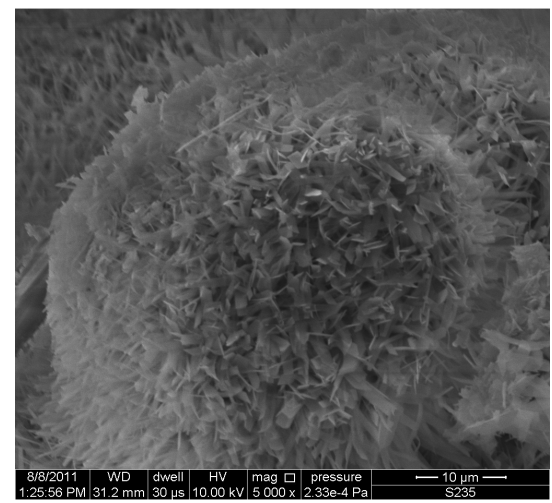

Fig. 1. A grain of sand surrounded by the C-S-H phase and the tobermorite in the product with $1 \%$ of organic substance admixture

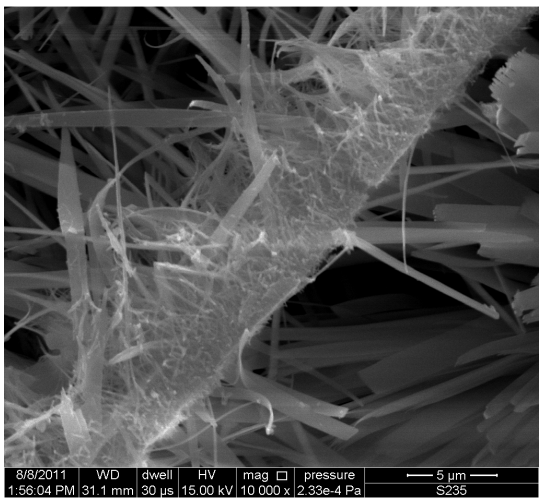

Fig. 2. Tobermorite

The degree of structure arrangement in the products formed during autoclaving, depending on the synthesis conditions, can vary from almost amorphous to the crystalline form, hence the phase diversity (Figs 1, 2).

Figure 1 shows a sand grain $\mathrm{SiO}_{2}$ surrounded by the tobermorite phase. C-S-H phase, which is formed before the tobermorite as amorphous phase, often takes the form of a spongy or fibrous (Fig. 4). It should be noted that amorphous phases of hydrated calcium silicates have a largest surface area, which decreases rapidly as a result of ordering the structure, which is caused by the hydration process.

Figure 2 shows the tobermorite with a lamellar cross-section (or in the form of blades) and amorphous CSH phase. "Blades" (mentioned lamellae) of tobermorite have flat endings. The shape of the individual phases depends on the method of obtaining sand-lime mass ingredients and mixing process, the amount of added water, temperature, pressure and time of mixing, preparation and autoclaving. According to Taylor, there are three phases of a tobermorite, which differ from one another by the interplanar spacings and the length of the $\mathrm{SiO}_{3}$ chains. In order to correct determination of the phase variety, the analysis of $\mathrm{Ca}$ to $\mathrm{Si}$ content $(\mathrm{C} / \mathrm{S})$ should be performed. In the internal (phase) structure of silicate materials the formation of jennite is impossible. This is influenced by a small content of calcium $(\mathrm{Ca})$ with respect to silicon ( $\mathrm{Si}$ ). 


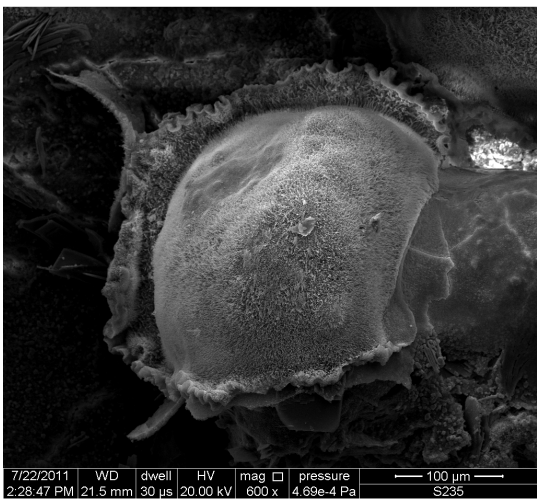

Fig. 3. A grain of sand surrounded by the tobermorite in the product with $5 \%$ of organic substance admixture

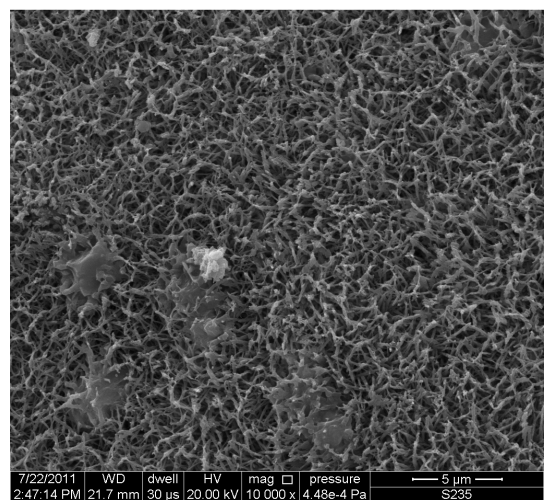

Fig. 4. CSH phase in the product with $5 \%$ admixture of organic substance

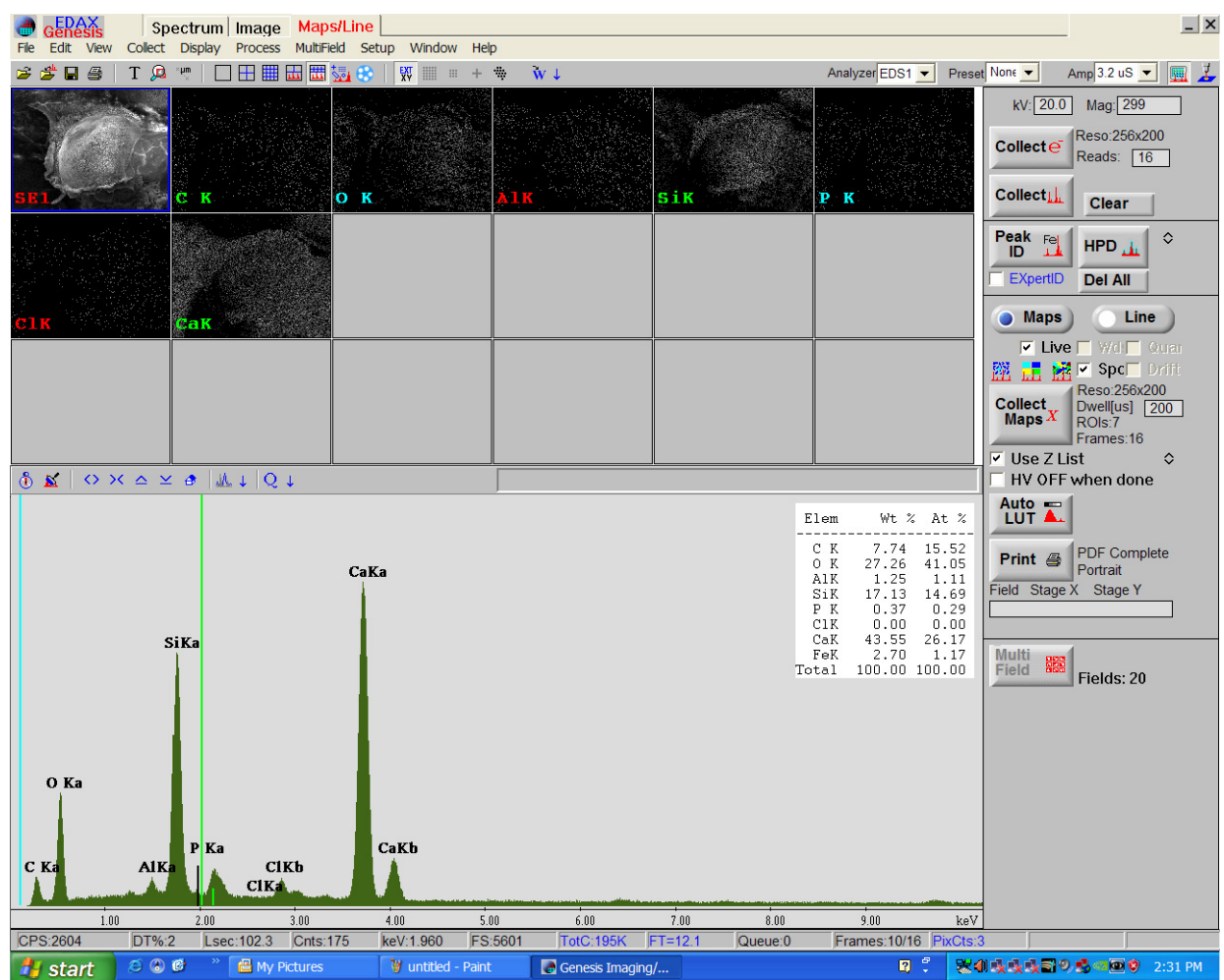

Fig. 5. EDS spectrum in the studied area of the sand-lime product modified with $5 \%$ admixture of organic substance

The following figures show the image of the phase microstructure of silicate products modified with barite aggregate in combination with the organic substance in an amount of 5 and $10 \%$ (relative to the weight of the product). The experiment caused an increase in the compressive strength $(\sigma)$ of the modified silicate product (to the value of about $35 \mathrm{MPa}$ ) and increase its bulk density $(\rho)$ (at the level of $2.02-2.20 \mathrm{~kg} / \mathrm{dm}^{3}$ ), which is involved in improving of temperature and humidity conditions of not only single elements, but also the divisions made of them.

Figures 3 and 4 present the fragment of the sample modified with $5 \%$ of organic substance in liquid form. The fibrous $\mathrm{CSH}$ phase is well visible (Fig. 4). The fragment of tested product was subjected to EDS composition analysis, which showed the presence of elements such as potassium, chlorine or aluminum. Synthesis of tobermorite was faster and more efficient in the presence of aluminum (Al). This element is beneficial also for the stabilization of this phase. 


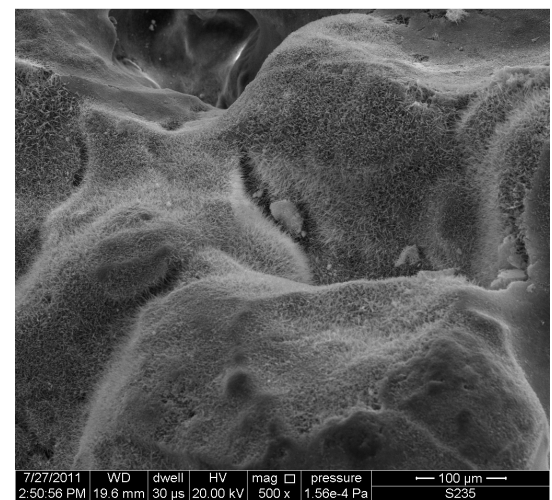

Fig. 6. A grain of sand surrounded by the C-S-H phase, the tobermorite, in the product with $10 \%$ of organic substance admixture

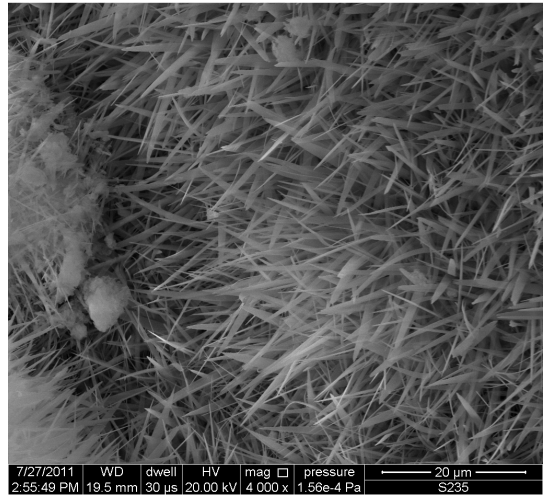

Fig. 7. Xonotlite forms in the product with $10 \%$ of organic substance admixture

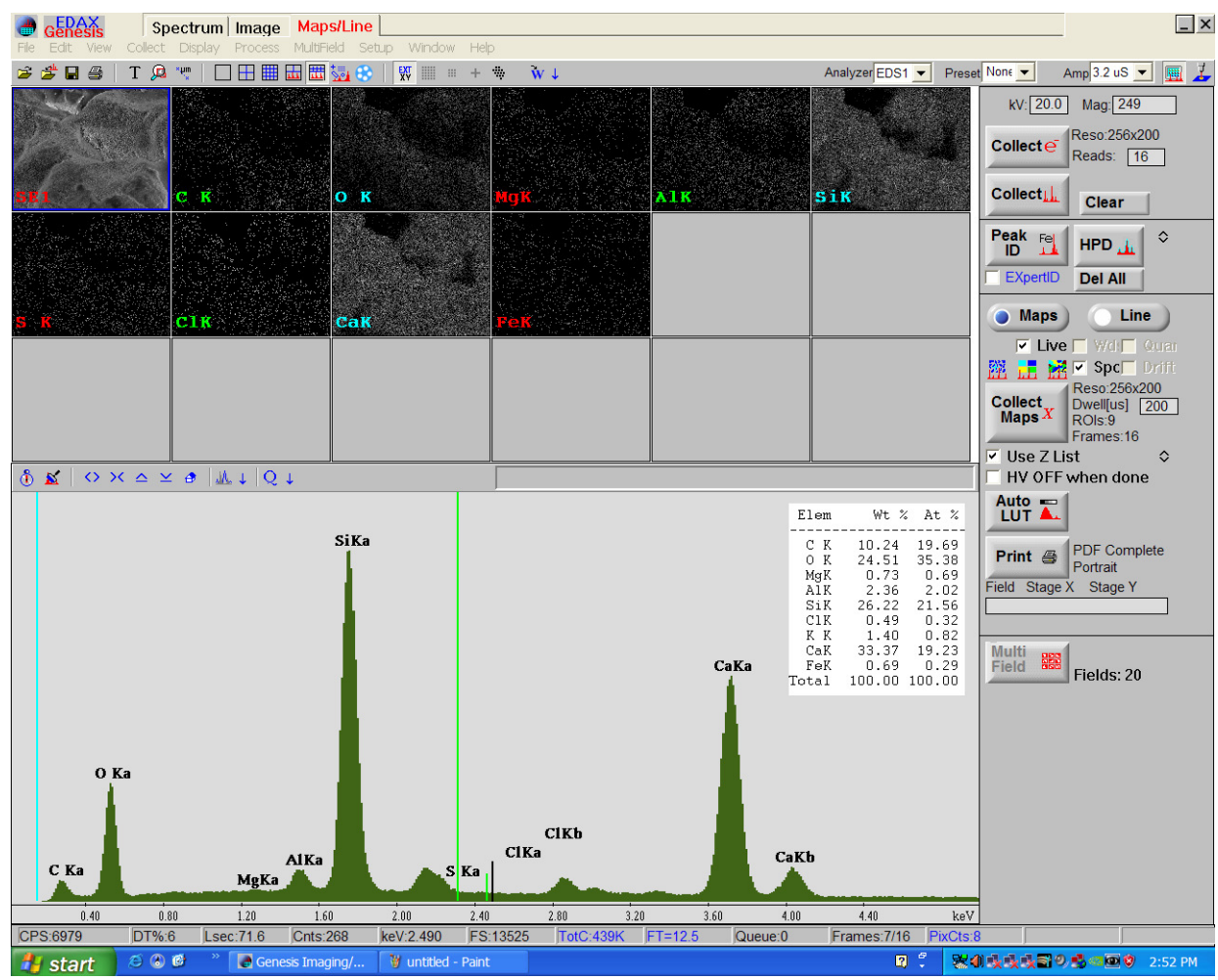

Fig. 8. EDS spectrum in the studied area of the sand-lime product modified with $10 \%$ admixture of organic substance

Figures 6 and 7 are the images obtained during the SEM examination of sand-lime product with $10 \%$ of organic substance (by weight of the product). In Figure 7 a xonotlite phase was separated, although it does not occur uniformly in the sample. This phase is referred to as high strength phase. X-ray diffraction, however, did not confirm its presence (but did confirm the presence of tobermorite). High strength phases are responsible for increasing the strength of the products, because they limit free spaces in modified product by filling them.

Figure 8 shows a qualitative analysis of the elemental composition (EDS analysis) in a given microarea of modified sand-lime product. Visible different content of silicon $(\mathrm{Si})$ and calcium $(\mathrm{Ca})$ indicates the presence of the sulfate phase.

Such analysis allows the identification of the elemental composition of tested element. The diffractogram showed the presence of the following elements in the microstructure: silicon, calcium, carbon, oxygen and a trace amount of aluminum. Aluminum advantageously stabilizes the tobermorite, but too large amount of this element or its derivatives inhibits the synthesis of xonotlite phase.

Generally, the correlation between compressive strength (and other functional properties) and the microstructure of sandlime products is assumed, but their internal structure is not sufficiently known yet.

Based on a preliminary scanning electron microscopy analysis cannot be clearly stated what level in the microstructure each phase occupies. For this purpose additional tests should be performed.

X-ray diffraction (XRD) confirmed the presence of quartz, which is composed primarily of silica dioxide and is the main constituent of silicates, aragonite or calcite (multiform varieties of calcium carbonate $\mathrm{CaCO}_{3}$ and the products of 
hydrothermal processes). A trace amount of rutile in the traditional silicate sample is related to the fact that this mineral often combines with quartz, and strictly speaking, creates so called inclusions in quartz. The peaks from the tobermorite are less noticeable (which is related to the angle of the test of the sample and its crystallinity) because XRD analysis is intended for testing the crystalline forms in various stages of crystallization and the most characteristic peaks or phases are not always visible.

\section{Conclusions}

The most advantageous sample proved to be the one with the organic substance amount equal to $5 \%$ relative to the weight of the product.

1. Introduction to sand-lime mass $5 \%$ of the organic substance resulted in the synthesis and stabilization of the tobermorite phase in the microstructure of the product and led to a nearly twofold increase in the compressive strength of the modified product.

2. The compaction and arrangement of the microstructure in the modified products took place. The degree of sealing of the microstructure is therefore connected with used admixture and the compounds arising during chemical reactions.

3. As a result of the modification the bulk density has been improved.

4. The phase structure and the volume and shape of the pores affect the surface area of the product. The greater the microstructure ordering degree, the lower its surface area is.

\section{References}

[1] Kurdowski, W.; Faza, C-S-H. 2008. Stan zagadnienia. Cz. 2, Cement Wapno Beton, Stowarzyszenie Producentów Cementu, 2008 , R. $13 / 75$, nr 5.

[2] Taylor, H. F. W.; Roy, D. M. 1980. Structure and composition of hydrates, in Proc. 7th Int. Symposium on the Chemistry of Cement, Paris, 1980.

[3] Nonat, A. 2005. The Structure of C-S-H, Cement Wapno Beton Rok X/LXXII, Marzec-Kwiecien 2005, nr 2.

[4] Weller, H. O. 1921. M.Inst.C.E. B.Sc., Sand-lime and other concrete bricks. Department of scientific and industrial research, London 1921.

[5] Dachowski, R.; Stępień, A. 2011. The impact of various additives on the microstructure of silicate products, in International Conference on Green Buildings and Sustainable Cities (GBSC 2011), Bologna, Italy. Procedia Engineering 21 (2011) s. 1173-1178

[6] Jasińska, I.; Nowek, M. 2013 Wpływ modyfikacji wyrobów silikatowych dodatkiem w postaci LDPE na ich podstawowe właściwości użytkowe, in Wybrane problemy naukowo-badawcze budownictwa i inżynierii środowiska, in MDT Conference Plock 2013, p. 153-158

[7] Dachowski, R.; Stępień, A. 2012.Wpływ modyfikacji wyrobów silikatowych związkami organicznymi na ich mikrostrukturę i właściwości mechaniczne, Archiwum Instytutu Inżynierii Ladowej 13: 57-62. ISSN 1897-4007

[8] Antypina, A. S. 2005. Sostawy i technologia termostoikich materiatów na osnowie kompozicji wollastonita s izwiestkowo - kremnieziemistym wiażuścim, Autoreferat dysertacji, Tomsk 2005, 22 str

[9] Nocuń-Wczelik, W. 1999. Struktura i najważniejsze właściwości wybranych uwodnionych krzemianów wapniowych, CERAMICS 59, 1999, Polish Ceramics Biuletyn 21.

[10] Taylor, H. F. W. 1964. The Chemistry of Cements. Academic Press, London 1964.

[11] Kurdowski, W. 2010. Chemia cementu i betonu, Wydawnictwo Naukowe PWN Warszawa 2010.

[12] Parker, P. M.; Lilly, E. 2005. The 2006-2011 World Outlook for All Silica. Brick and Shapes Excluding Semi-Silica. INSEAD (Singapore and Fontainebleau, France) ICON Group International, Inc. 2005.

[13] PN-EN 772-1:2011 Met.badań elementów murowych. Cz. 1: Określenie wytrzym.na ściskanie.

[14] $P N-E N$ 771-2 Wymagania dotyczące elementów murowych. Część 2.

[15] PN-EN 772-13:2001 „Metody badań elementów murowych. Część 13

[16] $P N-E N$ 772-11 "Metody badań elementów murowych. Część 11. 